\title{
Realizing the Strategy of Ideological and Political Work for College Students with Red Culture Innovation
}

\author{
Wang Lin \\ Dalian Vocational and Technical College, School of Business Administration, Dalian 116035, China
}

Keywords: Red culture; Ideological and political work in colleges and universities; College students

\begin{abstract}
Red culture promotes ideological and political work in colleges and universities which clarifies working principles, standardizes work processes, adheres to the combination of inheritance and innovation, combines education and self-education, and combines normalization and flexibility; It also perfects operational mechanism, strengthens institutional guarantee, and innovates feedback evaluation and normalizes system guarantee; The promotion of red culture builds a relative education and teaching system, develops a red culture network publicity platform and builds a red campus culture and practice base.
\end{abstract}

\section{以红色文化创新高校学生思政工作实现策略}

\author{
王琳
}

大连职业技术学院 工商管理学院, 辽宁 大连 116035

关键词: 红色文化; 高校思政工作; 大学生

摘要：红色文化推进高校思想政治工作要明确工作原则、规范工作过程，坚持继承性与创新 性相结合、教育与自我教育相结合、规范性与灵活性相结合; 完善运行机制、强化制度保障, 创新过程性反馈评价、持续性激励机制、常态化制度保障; 构建红色文化的教育教学体系, 研发红色文化的网络宣传平台，建设红色校园文化及实践基地。

\section{1.引言}

高校思想政治工作历来受到我党的高度重视。随着我国经济快速发展，社会随之发生很 大变化, 这些变化对青年学生的影响很大, 对其人生观、价值观都带去重大改变, 而新形势 下对于大学生这样一个十分重要的群体, 如何做好其思想政治教育工作, 是一项艰巨的任务, 必须坚持实事求是，从发展的实际出发，继承优良的工作传统，谋划新思路、创新新载体、 找对新方法。

红色文化对推进高校思想政治工作具有重要作用，是一种独特的、优秀的思想政治教育 资源，对他们正确世界观、人生观、价值观的形成具有重要意义，有利于增强学生的爱国热 情, 它还有助于加强国家的自豪感和认同感, 维护自己国家的利益与荣誉, 将个人命运同国 家命运紧密联系在一起，并自觉的传承红色文化精神。

\section{2. 明确工作原则，规范工作过程}

\section{1 继承性与创新性相结合}

红色文化作为中国共产党的主要精神，蕴含着党的执政理念、精神境界和价值诉求，其 自身要求结合现实, 合理规划, 形成高校红色文化教育体系, 在其发展过程中, 我们需要把 
理论和现实相结合, 坚持继承与创新, 将红色文化阐述清楚, 从发展的历史与背景到其精神 的深意与影响。

\section{2 教育与自我教育相结合}

拓宽红色文化传播途径，把红色文化渗透到大学生学习生活实践全过程，开展红色文化 的教育课程、红色文化的实践活动、微信公众号推广和红色网站等, 结合第一课堂与第二课 堂的传播优势, 通过学校教育宣传、学分要求、实践需求等“规定性”要求引导学生养成教育 接受规律，促进大学生从“要我学”到“我要学”的转变, 达到教育与自我教育（“非规定性”） 的充分结合。

\section{3 规范性与灵活性相结合}

其实无论是革命博物馆、战争遗址还是革命故事、歌曲等红色文化成果资源是非常丰厚 的。我们要坚持用马克思主义的方法论规范性地对待已有资源, 亦要灵活运用已有资源, 结 合工作实际，用具体问题具体分析的、理论联系实际的、知行合一的方法来将红色文化推广 开来, 并大学生们充分感受到红色文化的鬼米力。引导大学生们广泛参与红色活动中去提高认 知、增强认同及提升理解。

\section{3.完善运行机制，强化制度保障}

\section{1 红色文化创新的过程性反馈评价}

红色文化是中国共产党人、先进知识分子和广大人民群众在战争和革命过程中创造的先 进文化，具有明显的中国特色。运用红色文化所蕴含的优秀文化因素，探索大学生思想政治 教育的新方法、新思路, 这对大学生自身具有重要的现实意义。而红色文化创新对于更是对 于红色文化的发展来说是一个必不可缺的一部分, 红色文化的创新及其过程需要在大学生思 政教育反馈评价过程中得到传承与发展。

\section{2 红色文化创新的持续性激励机制}

红色文化作为一种不断创新的文化，它的发展对于大学生的激励是一个持续性的过程, 现阶段的红色文化教育对于大学生来说不仅仅会让大学生学习到红色文化的起源和发展历 程, 更会对我们起到一个激励与引导的效果。现阶段的高校对于红色文化的创新不仅需要重 视, 更要采取创新的持续性地激励机制, 如积分兄换、学分奖励等, 促进这一问题地长效地 发生作用。

\section{3 红色文化创新的常态化制度保障}

继承红色文化为巩固党的执政地位提供了有力的政治保障。红色文化不仅承载着党领导 群众进行革命和建设社会主义的过程, 而且体现了党的艰苦奋斗、为人民服务、不怕牺牲的 精神。只有将红色文化宣传教育以常态化的制度保障确立下来, 使大学生提升红色文化学习, 加强红色信仰自觉, 为巩固社会主义核心价值观奠定基础, 它也是社会主流意识和正能量传 播的前提和保证。

\section{4.构建红色文化的教育教学体系}

红色文化资源以事实为依据, 以历史为主线, 以不同的角度真切的记录了老一辈共产党 人为了追求理想, 追求改革开放的奋斗历程, 让大学生真正的领悟到了什么是榜样的力量, 改变了传统的教育模式, 强化了高校的教育效果。 


\section{1 高校各级党课为核心的价值引领}

高校作为我国培养高素质人才的重要基地, 肩负着培养中国特色社会主义事业合格建设 者和可靠接班人的重要使命。高校党建工作是思政教育的重要组成部分, 各高校及二级学院 纷纷开展着校院两级的党课来引领优秀大学生、开展高校党员教育管理工作。高校的党课培 训内容务必有党的成立、发展、建设等方面的内容，这与红色文化不可分割。

\section{2 红色文化融入思想理论课堂教育}

现在大学的思想教育存在的最大的问题就是老师与学生之间没有互动, 老师在讲台上将 自己的, 学生在下面玩自己的, 最后一节课下来, 学生什么都没学会。单纯的为了讲课而讲 课, 并没有讲到学生的心中。将红色教育融入的思政教育过程, 如形势与政策与毛泽东思想 概论等课程。这些课程都深深地将红色文化融入到了课程学习当中, 提高着大学生对中国特 色社会主义的理论、政治和情感认识。

\section{3 大力挖掘宣传利用本土红色文化}

地方红色文化资源具有浓厚的历史背景。蕴含着老一辈人民崇高的理想信念具有强烈的 说服力, 震撼力, 具有强大的视觉冲击感。这在大学生的爱国主义和理想信念教育中起着非 常重要的作用。高校让这些本土红色资源与平日的教学相结合, 这可以让一些课程更加丰富 有趣，而这些本土红色资源更可以让学生参与其中、感受其中、置身其中。

\section{5.研发红色文化的网络宣传平台}

\section{1 建立校园红色专题网站}

学校通过建立红色宣传网站, 设置后台维护人员、文案编辑人员及意见领袖, 定期推送 更新、发表评论, 如传承英烈精神的文章, 党的优秀同志的相关事迹的视频, 通过物质、精 神故事和角色感召力, 用情感打动和感染人们。我们可以推送当地相关红色遗址、英烈人物 精神事迹, 这样有较强烈的代入感, 容易引发共鸣。在这一过程中要注意选取适当的演示表 达形式, 以学生喜闻乐见的表达和观看形式展现出来。另外还可以要求组织学生定期打卡观 看，设有相关学习科目，完成答题测试，使其充分感受“红色文化”。

\section{2 开通红色微博或公众号}

在新时代的网络环境下, 新媒体正在改变着我们获取信息的习惯。只有赶上时代的大潮, 充分利用新媒体, 改变宣传方式, 才能更好更快地发展和传播红色文化。宣传人员通过公众 微信号、微博等向大学生提供便捷的渠道, 让红色文化的感召和影响无处不在, 增强红色文 化对公众的吸引力。新媒体以文字、图片、音像等形式, 展现更为丰富多样的红色文化, 引 导公众积极表达意见，它改变着传统媒体在时间和空间上的缺陷，实时的发布新闻，及时的 互动参与，广泛的弥漫散播使红色文化的发展速度更快、范围更广。

\section{3 红色文化主题教育活动}

红色标语、雕塑和肖像进入校园，历史性、场景性、象征性的营造校园红色教育的浓厚 氛围的营造。教室、宣传栏等通过故事板、宣传画等，讲座座谈会、征集论文、知识竞赛、 主题团日、党日活动等, 有效地开展学习宣传活动。充分利用爱国主义教育基地强大功能, 让学生亲身感受红色文化的精神, 积极开展各类形式的红色文化活动, 让大学生代入式地置 身其中, 激发学生的爱国激情, 使学生在实践中体味、品读、修炼, 坚定学生承担民族复兴 的历史责任信念。 


\section{6.建设红色校园文化及实践基地}

\section{1 红色文化主题长廊}

营造新的文化环境，使红色文化遍布到学校的每个角落，宣传当地红色内容的故事、英 烈图片、名人名言、设置宣传栏、黑板报纸、标语等形式的宣传, 让学生感受到红色的魅力。 建设校外实践基地, 寻找具有本土红色历史的地方, 并在追溯历史故事、爱国警句中确立了 红色文化的宣传主题。

\section{2 红色文化社团活动}

组织红色文化社团活动，可以开展参观、知识竞赛、红色文化征文等通过活动让同学们 聚在一起交流思想和感情, 深入理论学习, 线上线下组织红色文化研究会, 厚植爱国主义情 怀。

\section{3 红色文化主题宣讲}

开展教育性的“红色课堂”，突出了“红色演讲”、“红色展览”、“红色布道”等内容。包括学 习习近平新时代中国特色社会主义思想、十九大精神等学习课题, 组织大学生党员、优秀团 员开展学习讨论, 提高大学生群体的理论水平, 引导大学生创新组织发展, 树立服务群众的 榜样，开展优秀党员、团员“亮身份、树形象、做贡献”等宣讲活动。

\section{4 红色文化实践基地}

依靠当地的红色文化遗址，寻找感动时代人物，传承英烈精神，在时代语境中，革命精 神与当代先锋人物的事迹巧妙地融为一体。依托当地的红色资源, 不断探索、找准机遇, 大 力拓展主题内涵。将爱国主义教育基地从红色爱国主义的主题推向时代的先锋，努力在充分 利用现有红色文化基地的基础之上，创造新的实践模式，建立基地、走出基地，组织各种符 合青年人身心特点的活动，特别是他们喜欢的活动，并进行实践教育。

综上，红色文化及其精神实质为当前多元化价值观导向提供了价值衡量标准。它的特点 决定了其在高校思政教育工作中可以发挥政治导向、道德教化和文化安全等作用。弘扬红色 文化精神、运用红色文化力量、开发红色文化资源，构建高校思政教育工作的创新机制，成 为新时代高校思政教育工作的创新突破点，亦是反击历史虚无主义思潮，牢固占据高校意识 形态阵地的必然选择, 以红色文化作为保障, 迎着新时代的洪流, 大胆启航, 奋力前进, 做 一名新时代的弄潮儿，为了中华人民共和国的不断发展添砖加瓦。

\section{致谢}

本文系大连职业技术学院校级课题《以红色文化创新高校思政教育工作的实践研究》（课 题编号: DZ2019SZ-09) 研究成果之一。

\section{References}

[1] Peng Xianze, Liu Ting and Xia Yi. Research on the Value and Path of Integrating Red Culture into the Education of College Student Party Members [J]. School Party Building and Ideological Education, 2019 (6)

[2] Wang Ling, Chen Yulin. The Value and Realization of Red Cultural Resources in Ideological and Political Education in Colleges and Universities, Party Building and Ideological Education in Schools, 2018 (11)

[3] Zeng Jie. On the Time Value of Red Culture in Ideological and Political Education in Colleges and Universities [J]. School Party Building and Ideological Education. 2018 (15) 
[4] Wei Hai. Let Red Culture Become the Cultural Background of Deshu People [J]. People's Forum. $2019(4)$ 